\title{
Impact of Service Quality and Perceived Value on Customer Satisfaction and Behavioral Intentions: Evidence from Convenience Stores in Vietnam
}

\author{
Van Dat TRAN ${ }^{1}$, Nhat Minh Trang LE ${ }^{2}$
}

Received: June 28, 2020 Revised: July 19, 2020 Accepted: August 10, 2020

\begin{abstract}
This research investigates the relationship among product quality, service quality, perceived value, customer satisfaction, and behavior intentions. Validated measurements were identified from a literature review. The measurement model and the conceptual model depicting hypothesized relationships were evaluated based on responses from 220 customers using confirmatory factor analysis and structural equation modeling. The testing results show that, for the direct path, product quality has a significant, positive influence on customer satisfaction, and behavioral intentions. Also, perceived value directly influences customer satisfaction and behavioral intentions and satisfaction is an antecedent of behavioral intentions. For the indirect path, service quality has a significant, positive influence on behavioral intentions through the customer satisfaction. The major finding of this study suggest that service quality easily attract more customers, especially the young consumers. About the sale personnel, communication skills, knowledge and ways of treatment to customers are crucial to retailers to gain competitive advantage over competitors. Therefore, it should have clear and consistent processes, procedures with criteria that create the best condition for organization and individual to open this kind of retailing store. Furthermore, product quality improvement is essential; all products must have clear originality; and diversifying products and services is also the way to appeal more consumers.
\end{abstract}

Keywords: Product Quality, Service Quality, Perceived Value, Customer Satisfaction, Behavior Intentions

JEL Classification Code: M30, M31, M37

\section{Introduction}

The globalization has been increased strongly between countries and the demand of purchasing fast-moving consumer goods of Vietnamese people is increasing as well, so there are many foreign convenience store chains have been opened in Vietnam such as FamilyMart and Ministop, which are Japanese convenience store chains, or Vietnam's own Shop \& Go and Circle K of the U.S, etc. They are opened to response the demand of customers. Convenient stores in Vietnam are popular places for local residents to

${ }^{1}$ First Author and Corresponding Author. Head, Marketing Department, Faculty of Business Administration, Banking University of Ho Chi Minh City, Vietnam [Postal Address: No.36, Ton That Dam Street, Nguyen Thai Binh Ward, District 1, Ho Chi Minh City, 710000, Vietnam] Email: dattv@buh.edu.vn

${ }^{2}$ School of Business, International University, Vietnam.

Email: minhtrangle238@gmail.com

(c) Copyright: The Author(s)

This is an Open Access article distributed under the terms of the Creative Commons Attribution Non-Commercial License (https://creativecommons.org/licenses/by-nc/4.0/) which permits unrestricted non-commercial use, distribution, and reproduction in any medium, provided the original work is properly cited. purchase everyday products daily lives. You can purchase different kinds of convenient products from toothpaste to milk at these shops with reasonable price and standard quality. Moreover, convenience store also offers several services such as providing fast food, store-cooked food and drink as customer's demand, and the consumers can stay there to enjoy or take away.

There are some related study conducted in several years ago but some gaps still exist. It may remain controversial what factors affecting customers' behavioral intention toward convenience stores in Vietnam. I have found there are just a few studies conducted in Vietnam, Vietnam about the convenience store topic and the conclusions seem not be clarified yet, so conducting this research is essential for further growth of convenience stores in Vietnam retailing industry. Importantly, such researches were carried out several years ago, so the information might be out-dated which can lead to incorrect information for retailers; the trend may change through time; the degree of influence from factors lead to purchase may not be the same as the past. Therefore, the conduct of this research is crucial because it helps to explain this issue in Vietnam, specifically in recent 
years. In sum, all past researches may have these main gaps: (1) out- dated information compares to the present, (2) nondiversify samples and limited scope leads to the difficulty and controversy in generating significant conclusion and recommendation. Therefore, it is essential to conduct another study related to finding out factors affecting consumers' behavioral intention toward convenience stores.

Cronin, Brady, and Hult (2000) clarified the relationships between quality, value, satisfaction, and behavioral intentions. The findings indicate that both service quality and service value are important determinant lead to satisfaction. Besides, the empirical results presented here indicate that the value of a service product is largely defined by perceptions of quality. Moreover, value, and satisfaction directly influences behavioral intentions. However, this study still has the limitations. For example, this model is not designed to include all possible influences on consumer decisionmaking for services. Ryu, Lee and Kim (2012) shows that customer perceived value is indeed a significant determinant of customer satisfaction, and customer satisfaction is a significant predictor of behavioral intentions.

With the purpose to find out what factors affecting consumer behavioral intention in retailing industry, if success, it is significant and vital for performance improvement of convenience store in harsh competition with both domestic and foreign rivalries. Moreover, through clearly classify which factors are favorable, which are unfavorable and the detailed degree of them from most to least effect, the retailer also have right strategies to satisfy customers. Findings result in this study will help retailers of convenience store find ways to differentiate themselves to others such as supermarkets, traditional market, etc. to win their customers. Therefore, research about factors affecting consumer behavioral intention in modern retailing industry is necessary to conduct. In addition, this research is useful in providing literature and knowledge for further future research on this topic. Based on the problem statements, conducting the study about factors affecting behavioral intention toward convenience store in Vietnam with the aims to:(1) find out the factors influencing customer's behavioral intention towards convenience stores; (2) categorize factors from most to least effective in behavioral intention of consumer in convenience stores industry; (3) provide recommendations for the marketers and strategy makers can find out suitable ways to do higher performance and get higher profits for the corporation that contributing to growth of the convenience stores.

\section{Literature Review}

\subsection{Behavioral Intension}

Ajzen (1991) argued that behavioral intentions effects how hard a person is willing to try, and how motivated a person is, to perform the behavior. In theory behavioral intentions is the most proximate predictor of behavior (Ajzen, 1991). Fishbein and Ajzen (1975) defined behavioral intentions as "a measure of the strength of one's intention to perform a specific behavior". Favorable behavioral intentions are associated with a service providers' ability to make its customers: say positive things about them (Boulding, Kalra, Staelin, \& Zeithaml, 1993). Tran (2020) confirmed that service quality influences experience values, relationship quality and purchase intention. Service quality, experience value, relationship quality and behavior intentions altogether are not well understood in current literature despite the important implication for managers, academicians and consumers alike. Accorrding to Cha and Lee (2020), factors as 'diversity', 'safety' were revealed to significantly affect hedonic customer value, while 'convenience' was shown to affect utilitarian customer value significantly. In addition, the path that customer value leads to satisfaction was also found to be significant. The result of the study suggests that selection attributes of convenience store dessert and providing meaningful implications of related hedonic and utilitarian values when customers purchase dessert at convenience store. Similarly, customer satisfaction, and behavioral intentions such as intent to return and spread positive word-of-mouth (Ryu, Lee, \& Kim, 2011). Therefore, we use behavioral intention context to investigate about the satisfaction and experience influence on behavior of customers about convenience store.

\subsection{Product Quality}

Product quality mediated by satisfaction was evidenced in the study by Tsiotsou (2006). The concepts of quality and performance have been identified as determinants of satisfaction. In product-based industries, the primary determinant is product quality (Kotler, 1989), and is defined as a product's ability to perform its stated task (Kotler, 1989). In addition, Ryu and Han's (2010) study examined the relationships among three determinants of quality dimensions (food, service, and physical environment), price, customer satisfaction, and behavioral intention in quickcasual restaurants. Similarly, this study also attempted to understand the effects of three dimensions of foodservice quality on customer response in the restaurant industry. It is common that all three studies examined the influence of foodservice quality on customer satisfaction and behavioral intentions in the context of restaurant. Drawing on the previous findings, the following hypothesis is formulated:

\footnotetext{
H1: Product quality has significant positive impact on behavioral intention

H2: Product quality has significant positive impact on customer satisfaction
} 


\subsection{Service Quality}

For decades, many researchers have developed a service perspective (Zeithaml, 2009; Ramsaran -Fowdar, 2007). Chang (2008) described that the concept of service quality should be generally approached from the customer's point of view because they may have different values, different ground of assessment, and different circumstances. Parasuraman, Zeithaml and Berry (1990) mentioned that service quality is an extrinsically perceived attribution based on the customer's experience about the service that the customer perceived through the service encounter. Service quality is one of the most important constructs in their models, and has been found to be a positive impact of service quality on customer satisfaction (Cronin et al. 2000; Oliver, 1997). Previous studies suggest that customers' positive behavioral intentions come from their satisfaction, while satisfaction is the result of good service quality. Specifically, satisfaction is a strong mediator of the effect of service quality on behavioral intentions (Dabholkar et al., 2000). However, this research stream primarily discusses consumer behavioral intentions from the benefit aspect.

H3: Service quality has significant positive impact on customer satisfaction

\subsection{Perceived Value}

Offering the best value to customers is a continuing concern of management in many business markets nowadays. Zeithaml (1998) conceptualized service value as a consumer's overall assessment of the utility of a service based on perceptions of what is received and what is given. Perceived value has a positive effect on customer satisfaction (Gallarza \& Gil Saura, 2006). Moreover, researchers show that perceived value is not only an important antecedent of behavioral intentions, but also a new paradigm that offers a more comprehensive approach than simple focus on service quality or satisfaction (Martinez-Ruiz et al. 2010). Subsequent researchers also provide empirical evidence to support the link between perceived value and behavioral intentions (Jen \& Hu, 2003). However, other researchers further propose the relationship between perceived value and customer satisfaction. For example, Rust and Oliver (1994) note that value, like quality, is an encounter-specific input to satisfaction, which implicate the positive link between perceived value and satisfaction. Lapierre et al. (1999) also found empirical support for the positive effect of perceived value on customer satisfaction. Extant research confirms that customer perceived value has been accepted as a reliable predictor of customer satisfaction and consumer purchase behavioral intentions (Andreassen \& Lindestad, 1998; McDougall \& Levesque, 2000; Patterson \& Spreng,
1997; Ryu et al., 2010). Based upon these research results, we propose that:

H4: Perceived value has significant positive impact on customer satisfaction

H5: Perceived value has significant positive impact on behavioral intention

\subsection{Customer Satisfaction}

Modern retailers believe that customer satisfaction is a major factor in doing successful business and customer satisfaction is responsible for store sales performance (Gomez, McLaughlin, \& Wittink, 2004). In addition, customer satisfaction refers to customers' feelings of satisfaction or dissatisfaction arising from comparing a product's or service's performance or outcome along with their expectation (Kotler \& Keller, 2006). In addition, Won and Kim (2020) showed consumer attitude is also positively related to purchase intention in the fashion-sharing platform. Besides, product risk, privacy risk, and perceived satisfaction influenced purchase intentions. In addition, many researchers provided empirical evidence of a positive relationship between customer satisfaction and behavioral intentions. Kim and Yang (2020) showed that overall, external and internal selection factors had a positive influence on repurchase intentions, and in particular, appealing to internal and external selection factors in order to promote repurchase intention. For instance, in their empirical investigation of the link between dining satisfaction and postdining behavioral intentions, Kivela, Inbakaran, and Reece (1999) found that dining satisfaction significantly influences behavioral intentions. These findings all support the significant link between customer satisfaction and behavioral intentions in the restaurant industry. Numerous studies confirm the positive and direct association between customer satisfaction and behavioral intentions, such as repurchase and word-ofmouth communication (Han \& Ryu, 2009; Kim et al., 2009; Kivela et al., 1999; Namkung \& Jang, 2007; Oliver, 1997; Ryu $\&$ Han, 2010). Thus, the following hypothesis was developed.

H6: Customer satisfaction has significant positive impact on behavioral intention

\section{Research Methodology}

\subsection{Research Framework}

The purpose of this research is to examine the relationships among product quality, service quality, perceived value, customer satisfaction, and behavioral intentions for Vietnamese shoppers. As the literature above, the conceptual framework for this study is constructed as below: (see Figure 1). 




Figure 1: Research framework

\subsection{Measurement Scale}

The main purpose of this study is to find out what factors affecting customer behavioral intention toward convenience store in Vietnam, therefore, the nature of study is exploratory and it aims to be a descriptive and analytical research. Scale measures of construct in this study were borrowed mainly from the existing scales that have been shown to be reliable and valid. Seven- point Likert scales were adopted to measure items like product quality, service quality, perceived value, customer satisfaction, behavioral intention. All items were measured by a seven-point Likert scale, anchored by 1 : strongly disagree and 7: strongly agree. Based on literature review, the variables of research are measured as table below. (see Table 1).

\subsection{Sample and Data Collection}

In data collection process, a total of 220 questionnaires are given out to respondents by paper questionnaires. However, 20 questionnaires are disqualified because of missing answers and which were not fully completed. As a result, the final results obtained 200 questionnaires that qualified the criteria of the study and analyzed for further findings. Hence, the response rate is about $90.9 \%$. Among 200 participants, there are $40.5 \%$ males and $59.5 \%$ female. The surveys were delivered to all male and female in different convenience stores around Vietnam but the number of female who were interested in the research is higher. Besides, this result shows that female is more interested in shopping than male and the wife is mainly a person who purchases goods for the family. This research focuses on all potential customers of fast moving consumer goods at convenience store at all ages. However, in order to assure of updated information the target sample of respondents is restricted by requirement of purchasing the products and services of convenience stores within 6 months. The ages' respondents range from less than 18 years old to over 40 years old. The majority of respondents participating in this research are young ranging from 18 to 25 that accounts for $82.5 \%$, in which the group of under 18 age accounts for $12.5 \%$; the percentage of respondents ranging from 26 to 40 makes up $12.5 \%$, and the group of middle-aged participants which is age 40 above constitutes only $1 \%$. From that result, convenience store is very popular with young people while convenience stores still cannot reach to middle-aged people and motivate them to shop there.

\section{Results and Discussion}

\subsection{Reliability Analysis}

In a research, the reliability test is to calculate the degree of internal consistency of a variable. The most common measurement scale of reliability is Cronbach's alpha. There are a number of different aspects to reliability, one of the most commonly used index for testing the reliability of a multi-scale measurement tool - is an index of scale's internal consistency. The purpose of this test is to assess whether all items are measuring the same thing or internal consistency (DeVellis, 1991).

Based on the "coefficient of Cronbach's Alpha", we can assess the reliability of each factor. In addition, according to Nummally (1978) the "Cronbach's alpha if item deleted" is considered. If this rate of each variable is greater than the corresponding Cronbach's alpha coefficient, it should be removed to increase the reliability of scale. Finally, the variable has the "corrected item total correlation" is less than $0.3(<0.3)$ is considered as waste variable, does not have correlation with other variables, and of course excluded from the scale (Nunally \& Burnstein (1994))

Following the reliability statistics, Cronbach's Alphas value of all factors are very high, ranging from 0.908 to 0.955 , which proves that the measurement set is well-designed and internally consistent. Besides, all the items in all dimensions have Corrected item-total correlation are greater than 0.3 and all Cronbach's alpha if deleted less than Cronbach's alpha coefficient, so all items are remained for further analysis. 
Table 1: Respondent Profile

\begin{tabular}{|c|c|c|}
\hline Coded & Measurement Items & References \\
\hline \multicolumn{2}{|c|}{ Product Quality } & \multirow{5}{*}{$\begin{array}{l}\text { Jang and } \\
\text { Namkung, } 2007 \\
\text { Jang and } \\
\text { Namkung, } 2009\end{array}$} \\
\hline PQ1 & Convenience stores offer high quality products & \\
\hline PQ2 & Convenience stores offer a variety of items & \\
\hline PQ3 & Convenience stores offer fresh food & \\
\hline PQ4 & The product presentation was visually attractive and has easy-picking product arrangement & \\
\hline \multicolumn{2}{|c|}{ Service Quality } & \multirow{3}{*}{$\begin{array}{l}\text { Brady and Cronin, } \\
2001\end{array}$} \\
\hline SQ1 & The employee in convenience store understands the customer needs & \\
\hline SQ2 & The employees served me food exactly as I ordered it & \\
\hline SQ3 & The employees provided prompt and quick service & \multirow{2}{*}{$\begin{array}{l}\text { Jang and } \\
\text { Namkung , } 2009\end{array}$} \\
\hline SQ4 & The employees made me feel comfortable in dealing with them & \\
\hline SQ5 & The employees provide in-depth information of the product/service & \multirow{3}{*}{$\begin{array}{l}\text { Parasuraman, } \\
\text { Zeithaml and } \\
\text { Berry's, } 1985\end{array}$} \\
\hline SQ6 & The employees are always willing to help me & \\
\hline SQ7 & Generally, the physical facilities and employees are neat and clean & \\
\hline \multicolumn{2}{|c|}{ Perceived Value } & \multirow{7}{*}{$\begin{array}{l}\text { Ryu et al., } 2008 \\
\text { Sweeney and } \\
\text { Soutar, } 2001 \text { Lee } \\
\text { and Overby, } 2004\end{array}$} \\
\hline PV1 & The convenience store provides me great value as compared to others & \\
\hline PV2 & The shopping experience in convenience store was worth the money & \\
\hline PV3 & Making a purchase from this convenience store is an efficient way to manage my time & \\
\hline PV4 & This convenience store offers a wide selection of products/services, which meets my needs & \\
\hline PV5 & $\begin{array}{l}\text { The price of the products/services I purchased from this convenience store is at the right } \\
\text { level, given the quality }\end{array}$ & \\
\hline \multicolumn{2}{|c|}{ Customer Satisfaction } & \\
\hline CS1 & I am very satisfied with my overall experience at this convenience store & \multirow{4}{*}{$\begin{array}{l}\text { Oliver, } 1997 \\
\text { Ryu et al., } 2008\end{array}$} \\
\hline CS2 & I felt enjoyable to go shopping at convenience stores & \\
\hline CS3 & Overall, I am satisfied with the decision to purchase from this convenience store & \\
\hline CS4 & My choice to purchase in this convenience store was a wise one & \\
\hline \multicolumn{2}{|c|}{ Behavioral Intension } & \multirow{5}{*}{$\begin{array}{l}\text { Zeithaml et al., } \\
1996\end{array}$} \\
\hline $\mathrm{BI} 1$ & I would like to come back to this convenience store in the future & \\
\hline $\mathrm{Bl} 2$ & I would recommend this convenience store to my friends or others & \\
\hline $\mathrm{BI3}$ & I would say positive thing about this convenience store to others & \\
\hline $\mathrm{B} 14$ & I would encourage others to go to this convenience store & \\
\hline
\end{tabular}

\subsection{Testing Measurement Model with CFA}

According to two-step analysis of Anderson and Gerbing (1988), before conducting the structural equation model analysis to test the hypotheses of the research in structural model and analyze the impact of each path in the research framework, the confirmatory factor analysis should be conducted first to examine the validity and reliability of the measurement model. The purpose of testing the measure model is evaluating the rationality of the measurement proposed model before identify whether the hypotheses are supported. The measurement model is valid when the scale confidently measures what they are proposed to do in the research.

Model fit measure: In order to measure the model fit, the criteria that all the variable loadings in Standardized Regression Weight are greater than 0.5. Besides, there are some criteria to test the fitness of model (see Table 2). 
Table 2: Goodness-of-fit measures

\begin{tabular}{|c|c|}
\hline Measure & Threshold \\
\hline Chi-square/df (cmin/df) & $\begin{array}{l}\leq 2 \text { good; } \leq \\
5 \text { sometimes } \\
\text { permissible }\end{array}$ \\
\hline Goodness of fit index (GFI) & $\begin{array}{l}\geq 0.9 \text { : acceptable; } \\
\geq 0.8 \text { : marginal }\end{array}$ \\
\hline $\begin{array}{l}\text { Adjusted goodness of fit index } \\
\text { (AGFI) }\end{array}$ & $\geq 0.80$ \\
\hline Comparative fit index (CFI) & $\begin{array}{l}\geq 0.95 \text { great; } \\
\geq 0.90 \text { traditional; } \\
\geq 0.8 \text { sometimes } \\
\text { permissible }\end{array}$ \\
\hline $\begin{array}{l}\text { Root mean squared error of } \\
\text { approximation (RMSEA) }\end{array}$ & $\begin{array}{l}\leq 0.05 \text { good; } \\
\leq 0.08 \text { moderate }\end{array}$ \\
\hline Probability close (P) & $\geq 0.05$ \\
\hline Tucker Lewis index (TLI) & $\geq 0.9$ \\
\hline
\end{tabular}

Source: Hair et al. (2006)

Besides model fit indices, there are some criteria to measure construct validity as below according to Hair et al (2010): Composite Reliability (CR) $>0.7$, convergent Validity: CR > Average Variance Extracted (AVE) AVE > 0.5, Discriminant Validity: Maximum Share variance (MSV) $<$ ABE Average Share Variance $(\mathrm{ASV})<$ AVE. CFA was conducted in order to verify whether or not the measurement model fits with the data from survey.

In this study, all the criteria are met, therefore, the research model was considered structurally fit by the conventional criteria for acceptable model fitness. In addition, the table 3 and table 4 shows that all the standardized regression weights are greater than 0.5 , and in the table, all P-value are equal $0.000(<0.05)$ that qualify the criterions. Therefore, no item of factors in this model needs to be deleted and all the items of factors are kept in this research for the next step of the data analysis process (see Table 3)

Although Cronbach's alpha provides the satisfactory result about the reliability of this study, construct validity (including convergent validity and discriminant validity) and construct reliability of the model are tested by looking at the value of Composite Reliability (CR) and Average Variance Extracted (AVE) to reassess the internal consistency of a measure with similar items (Fornell \& Larcker, 1981).

In the term of SEM, the reliable indicator defined as the squared standardized multiple correlation coefficient which is higher than a standard level at 0.7 (Bollen, 1989; Joreskog $\&$ Sorbom, 1993). The results provided the satisfactory results that $\mathrm{CR}$ of all constructs has estimated and loaded between 0.908 and 0.955 , Convergent validity was assessed in terms of factor loadings and average variance extracted.
Table 3: Model fit in CFA

\begin{tabular}{|l|c|l|}
\hline Model fit index & Score & \multicolumn{1}{c|}{ Criterion } \\
\hline X2/d.f. & 1.517 & $\begin{array}{l}\leq 2 \text { good; } \\
\leq 5 \text { sometimes permissible }\end{array}$ \\
\hline RMSEA & .051 & $\begin{array}{l}\leq 0.05 \text { good; } \\
\leq 0.08 \text { moderate }\end{array}$ \\
\hline GFI & .872 & $\begin{array}{l}\geq 0.9: \text { acceptable; } \\
\geq 0.8: \text { marginal }\end{array}$ \\
\hline AGFI & .842 & $\geq 0.80$ \\
\hline Pclose & .430 & $\geq 0.05$ \\
\hline CFI & .971 & $\begin{array}{l}\geq 0.95 \text { great; } \\
\geq 0.90 \text { traditional; } \\
\end{array}$ \\
\hline
\end{tabular}

Definitely, AVE is a strict measure of convergent validity (Malhotra and Dash, 2011). The scales have convergent validity when all its items are connected to significant and high loadings at over 0.5 (Hair, et al, 2006). As shown in the table, all items had significant factor loadings higher than 0.50 . Average variances extracted ranged from 0.672 to 0.841 , suggesting adequate convergent validity. Thus, all factors in the measurement model had adequate reliability.

Besides, discriminant validity denotes the degree of distinct between contexts. Discriminant validity is tested by comparing the average variance extracted (AVE) with the square correlation between constructs (Fornell \& Larcker, 1981). AVE was greater than the squared inter-construct correlation between any pair of constructs, which supports the discriminant validity of the construct. Besides, in this research, the correlations matrix between two constructs are extracted from CFA and the result of the comparison between Shared Variances including Maximum Shared Variance (MSV) and Average Shared Variance (ASV) are calculated by Microsoft Excel 2010 (see Table 4).

In sum, there are positive and strong relationship between Product Quality, Service Quality, Perceived Value, Customer Satisfaction, and Behavioral Intention. Moreover, this research model has appropriated reliability, convergent validity, and discriminant validity of the constructs.

\subsection{Model Test}

Structural equation models (SEMs), also called simultaneous equation models, are multivariate regression models. These structural equations are meant to represent causal relationships among the variables in the model as well as the significance level among latent variables as well as the observable variables in the model. The criteria for evaluating whether or not SEM fits with data are totally the same as that for evaluating CFA. 
Table 4: Reliability and Validity test

\begin{tabular}{|l|c|c|c|c|c|c|c|c|c|}
\hline & CR & AVE & MSV & ASV & PQ & SQ & PV & BI & CS \\
\hline $\mathrm{PQ}$ & 0.908 & 0.712 & 0.403 & 0.339 & 0.844 & & & & \\
\hline $\mathrm{SQ}$ & 0.935 & 0.672 & 0.415 & 0.314 & 0.543 & 0.819 & & & \\
\hline $\mathrm{PV}$ & 0.915 & 0.684 & 0.514 & 0.381 & 0.553 & 0.469 & 0.827 & & \\
\hline $\mathrm{BI}$ & 0.955 & 0.841 & 0.656 & 0.454 & 0.593 & 0.572 & 0.695 & 0.917 & \\
\hline $\mathrm{CS}$ & 0.926 & 0.758 & 0.656 & 0.497 & 0.635 & 0.644 & 0.717 & 0.810 & 0.871 \\
\hline
\end{tabular}

Note: $\mathrm{CR}=$ Composite reliability, $\mathrm{AVE}=$ Average variance extracted, $\mathrm{MSV}=$ Maximum shared variance, $\mathrm{ASV}=\mathrm{Average}$ shared variance



Figure 2: Model Tests

The research model can be considered as the test of relationship between two independent variables - Customer Satisfactions and Behavioral Intention and three dependent variables - Product Quality, Service Quality, and Perceived Value. After conducting SEM, the overall result was acceptable including $\chi 2 / \mathrm{DF}=2.019 ; \mathrm{TLI}=0.934 ; \mathrm{CFI}=0.941$; $\mathrm{RMSEA}=0.072 ; \mathrm{GFI}=0.834$. As results shown in that most of relationships between variables are not only positive but also statistically significant at the 0.001 level. Furthermore, although the relationship between Behavioral Intention and Product Quality has p-value at 0.041 , all hypothesized relationship were statistical significance due to all P-value are less than 0.05 .

The relationship Customer satisfaction $->$ Behavioral intention has the highest Regression Weight (0.740) which means that Customer satisfaction has the largest positive impact on Behavioral intention $(\beta=0.740 * * *, p<0.001)$, supporting the hypothesis H6. In other words, the more customer satisfaction with purchasing at convenience store is, the more customers intend to repurchase and recommend others to shop at convenience store. Besides, the weight of relationship Product quality $->$ Behavioral is only 0.120 and P-value was 0.04 , that means product quality has smallest impact on the behavioral Intention compared to other relationships; the hypothesis H1 is accepted. Additionally, the table also shows that product quality, service quality and perceived value has moderately positive influence on customer Satisfaction $(\beta=0.224 ; \beta=0.340 ; \beta=423 * * *$, $\mathrm{p}<0.001$, respectively). So hypothesis H2, H3 and H4 are approved. Finally, the hypothesis $\mathrm{H} 5$ is also accepted because it has the positive weight of relationship Perceived value -> Behavioral intention with the p-value $<0.05$ (see Figure 2).

In short, it is concluded that all the initial hypotheses including $\mathrm{H} 1, \mathrm{H} 2, \mathrm{H} 3, \mathrm{H} 4, \mathrm{H} 5$, and $\mathrm{H} 6$ are accepted and are statistically significant. In other words, there is positive impact of product quality and perceived value on behavioral intention. Furthermore, product quality, service quality and perceived value have a significant impact on customer satisfaction. Finally, customer satisfaction has strongly positive influence on Behavioral Intention.

\section{Conclusions}

The aim of this study is to explore the external factors that drive consumer behavioral intention toward convenience store in Vietnam. In specific, this study tests the interrelationship among product quality, service quality, perceived value, customer satisfaction and behavioral intention. Based on statistical evidence, there are all 6 initial hypotheses being supported in this study. The findings of this study indicate that the product quality and perceived value has the direct impact on customer satisfaction and behavioral intention. In addition, there is statistically significant to infer that service quality directly positive impact on customer satisfaction 
and indirect effect to behavioral intention through customer satisfaction. Furthermore, customer satisfaction was the significant determinant of behavioral intention.

To be more specific, firstly there exist a positive relationship between product quality- customer satisfaction and product quality-behavioral intention (path estimate $=$ 0.28 ; and 0.12 , respectively). It means that if product quality increase by 1 unit, the customer satisfaction would go up by 0.28 units and behavioral intention would go up by 0.12 units. Moreover, its influence is similar to other variables' relationships.

\subsection{Managerial Implications}

As the result mentioned in the sample demographic part, the percentage of middle-age people that purchase goods and services at convenience store is only $1 \%$. That means the modern retailing style is not popular to the middle-age people; one of the reasons is that the advertising is not focused much on to attract the customers, especially the middle-age consumers. In fact, there are only $21 \%$ customers reach convenience store's advertisement, middle-age or older customers even do not know about the convenience store. Convenience store's advertising is very popular in foreign countries but most of convenience store chains in Vietnam do not have any official advertisements program; it just only has a few newspaper and magazines about convenience store in Ho Chi Minh and Hanoi. Hence, it is important to focus more on advertising by TV commercial advertisement, popular newspaper or online social media, making some convenience store shopping brochure/handbook, flyers to access more population and target customers. Moreover, from our research result, young consumers from under 18 age and 18-25-age range who shop at convenience store accounts for $90.5 \%$, this is am extremely ideal target for convenience store. Young consumers are the targeted market in retailing industry everywhere, managers should drive all retailing strategies in terms of 7Ps (Boom \& Bitner, 1981) to attract the youth. Moreover, retailers that can win young customers may eventually access the heart of those young customers' parents or grandparents. Therefore, when retailers can reach young segmentation, they can reach general market simultaneously.

Based on our study's result, the service quality has positively significant affect customer satisfaction $(\beta=.405)$, and higher customer satisfaction leads to higher customer behavioral intention, that means people will repurchase and recommend others to shop at convenience store if they have high customer satisfaction. Thus, emphasize on service quality easily attract more customers, especially the young consumers. There are some ways to improve service quality. About the sale personnel, communication skills, knowledge and ways of treatment to customers are crucial to retailers to gain competitive advantage over competitors. Moreover, because the youth is a major targeted market, retailers should recruit sale person at the similar age of customers (from 18 to at most 30) to make a closer environment between sale person and customers. Another one is need to be focused is the facilities, retailers should design store layout of convenience store in the way to make the buying process of customer more quickly in terms of check-out, finding consumers' needed products, easy movement around store and impress the customer at the first time. Besides, facilities at the store must be updated to keep up with the youth's interest. Furthermore, science and technology are developing strongly in a world, so the convenience store should apply some modern technologies to give the best and quickest service in order to satisfy the customers by using system management by modern and high technology system, high security system such as fire alarm, antitheft device, etc.

In addition, body of the States plays very important role in the economy; the retailing industry is not an exception. Thus, the government policy and solution from the body of States also helps to improve convenience stores sales. However, some products are not allowed to sell in convenience store that cannot response to the customers' demand and increase sales for the convenience store. In fact, most of Vietnam pharmacies close after $11 \mathrm{pm}$, the customers cannot find some products such as condom and pain release medicine, etc. at late night, so selling these kinds of products at convenience store is essential to response the customers' demand. Besides, although government encouraging retailing system but in fact some entrepreneurs still meet several difficulties because of complicated procedures in registering business, tax, location rent, etc. that consumes much time. Therefore, good management is very important; it should have clear and consistent processes, procedures with criterias that create the best condition for organization and individual to open this kind of retailing store.

Last but not least, promotion is also very important to improve sales of convenience store, $73 \%$ customers care about the promotion of convenience store. Therefore, giving present, discount, lottery, special promotion in traditional festival, buy 1 get 1 free or buy 2 get 1 free program, etc. are the ways should be more applied in order to attract consumers. Furthermore, product quality improvement is essential; all products must have clear originality; ensure to have good quality that good for customers' health and diversifying products and services is also the way to appeal more consumers.

\subsection{Research Limitations}

There are some limitations in this research. Firstly, our study considers modern retailing channel, which is convenience store only in Ho Chi Minh city due to limited 
time and resource; therefore, generalizations of the model results will only be established if additional studies consider the proposed approach for other locations around Vietnam. Secondly, female participated more actively in the study and were slightly over-represented in the sample. Thirdly, there are many different branded convenience stores, but we only choose top 5 convenience stores in Vietnam to do a survey. Last but not least, the size sample of study should be larger to improve and support validity and reliability result.

Acknowledging these limitations, for future research, more branded convenience stores may be included to increase the reliability of the research the sample size should be more representative for the population; it means that the further study should collect the data in different convenience stores in different locations around Vietnam. Further research would be necessary to extend our findings by incorporating situational or personal characteristics (e.g., first timers vs. repeaters) as moderators into the conceptual framework. Understanding consumer differences based on personal and situational characteristics is another opportunity for further research.

\section{References}

Ajzen, I. (1991).The theory of planned behavior. Organizational Behavior and Human Decision Processes, 50(2), 179-211.

Anderson, J. C., \& Gerbing, D. W. (1988). Structural equation modeling in practice: A review and recommended two - step approach. Psychological Bulletin, 103(3), 411-423.

Andreassen, T. W., \& Lindestad, B. (1998). Customer loyalty and complex services: the impact of corporate image on quality, customer satisfaction and loyalty for customers with varying degrees of service expertise. International Journal of Service Industry Management, 9(1), 7-23.

Booms, B. H., \& Bitner, B. J. (1980). Marketing strategies and organisation structures for service firms. In: J. Donnelly. \& W. R. George (Eds.), Marketing of services (pp. 47-51). Chicago, IL: American Marketing Association.

Boulding, W. A., Staelin, K. R., \& Zeithaml, V. A. (1993). A dynamic process model of service quality: From expectations to behavioral intentions. Journal of Marketing Research, 30(1), $7-27$.

Brady, M. K., \& Cronin, J. J. (2001). Some new thoughts on conceptualizing perceived service quality: a hierarchical approach. Journal of Marketing, 65(3), 34-49.

Cha, S. S., \& Lee, S. H. (2020). The effect of convenience store dessert on consumers value and satisfaction. Journal of Asian Finance, Economics and Business, 7(3), 191-199. https://doi. org/10.13106/jafeb.2020.vol7.no3.191

Chang, J. C. (2008). Taiwanese tourists perceptions of service quality on outbound guided package tours: A qualitative examination of the SERVQUAL dimensions. Journal of Vacation Marketing, 15(2), 164-178.
Cronin, J. J., Brady, M. K., \& Hult, G. T. M. (2000). Assessing the effects of quality, value, and customer satisfaction on consumer behavioral intentions in service environments. Journal of Retailing, 76(2), 193-218. https://doi.org/10.1016/S00224359(00)00028-2.

Dabholkar, P. A., Shepherd, C. D., \& Thorpe, D. I. (2000). A comprehensive framework for service quality: An investigation of critical conceptual and measurement issues through a longitudinal study. Journal of Retailing, 76(2), 139-173.

Devellis, R. F. (1991). Scale development: Theory and applications. Applied Social Research Methods Series 2. Thousand Oaks, CA: Sage Publications.

Fornell, C., \& Larcker, D. F. (1981). Evaluating structural equation models with unobservable variables and measurement error. Journal of Marketing Research, 18(1), 39-50.

Fishbein, M., \& Ajzen, I. (1975). Belief, attitude, intention, and behavior: An introduction to theory and research. Reading, MA: Addison-Wesley.

Gallarza, M. G., \& Gil Saura, I. 2006. Value dimensions, perceived value, satisfaction and loyalty: an investigation of university students' travel behaviour. Tourism Management, 27(3), 437-452.

Gomez, M., McLaughlin, E. W., \& Wittink, D. R. (2004). Customer satisfaction and retail sales performance: an empirical investigation. Journal of Retailing, 80(4), 265-278.

Han, H., \& Ryu, K. (2009). The role of the physical environment, price perception, and customer satisfaction in determining customer loyalty in the restaurant industry. Journal of Hospitality and Tourism Research, 33(4), 487-510.

Hair, F. J., Jr., Black, W. C., Babin, B. J., Anderson, R. E., \& Tatham, R. L. (2006). Multivariate data analysis. Upper Saddle River, NJ: Pearson Education.

Hsieh, W. (2012). A study of tourists on attraction, service quality, perceived value and behavioral intention in the Penghu Ocean Firework Festival. The Journal of International Management Studies, 7(2), 79-92.

Jen, W., \& Hu, K. C. (2003). Application of perceived value model to identify factors affecting passengers' repurchase intentions on city bus: A case of the Taipei metropolitan area. Transportation, 30(3), 307-327.

Jen, W., Tu, R., \& Lu, T. (2010). Managing passenger behavioral intention: an integrated framework for service quality, satisfaction, perceived value, and switching barriers. Transportation, 38(2), 321-342.

Kotler, P., \& Keller, K. L. (2006). Marketing management. Upper Saddle River, NJ: Pearson Education.

Kotler, P. (1989). The principles of marketing. Englewood Cliffs, NJ: Prentice Hall.

Kim, Y. E., \& Yang, H. C. (2020). The effects of perceived satisfaction level of high-involvement product choice attribute of millennial generation on repurchase intention: moderating effect of gender difference. Journal of Asian 
Finance, Economics and Business, 7(1), 131-140. https://doi. org/10.13106/jafeb.2020.vol7.no1.131

Kim, W. G., Ng, C. Y. N., \& Kim, Y. S (2009). Influence of international DINESERV on customer satisfaction, return intention, and word of mouth. International Journal of Hospitality Management, 28(1), 10-17.

Kivela, J., Inbakaran, R., \& Reece, J. (1999). Consumer research in the restaurant environment, part 2: Research design and analytical methods. International Journal of Contemporary Hospitality Management, 11(6), 269-286.

Lapierre, J. (2000). Customer-perceived value in industrial context. Journal of Business and Industrial Marketing, 15(2/3), 122-140.

Lee, E. J., \& Overby, J. W. (2004). Creating value for online shoppers: Implications for satisfaction and loyalty. Journal of Consumer Satisfaction, Dissatisfaction and Complaining Behavior, 17, 54-67.

McDougall, G. H. G., \& Levesque, T. (2000). Customer satisfaction with services: putting perceived value into the equation. Journal of Services Marketing, 14(5), 392-410.

Malhotra, N. K., \& Dash, S. (2011). Marketing research an applied orientation. London, UK: Pearson Publishing.

Martinez-Ruiz, M., Jimenez-Zarco, A., \& Izquierdo-Yusta, A. (2010). Customer satisfaction's key factors in Spanish grocery stores: Evidence from hypermarkets and supermarkets. Journal of Retailing and Consumer Services, 17(4), 278-285.

Namkung, Y., \& Jang, S. (2007). Does food quality really matter in restaurant? Its impact on customer satisfaction and behavioral intentions. Journal of Hospitality and Tourism Research, 31(3), 387-410.

Nunnally, J. C. (1978). Psychometric theory (2nd ed.). New York, NY: McGraw-Hill.

Nunnally, J. C., \& Bernstein, I. H. (1994). Psychometric theory (3rd ed.). New York, NY: McGraw-Hill.

Oliver, R. L. (1997). Satisfaction: A behavioral perspective on the consumer. New York, NY: McGraw-Hill.

Parasuraman, A., Zeithaml, V. A., \& Berry, L. L. (1985). A conceptual model of service quality and its implication for future research. Journal of Marketing, 49(4), 41-50.

Patterson, P. G., \& Spreng, R. A. (1997). Modeling the relationship between perceived value, satisfaction and repurchase intentions in a business-to-business, services context: an empirical examination. International Journal of Service Industry Management, 8(5), 414-434.
Ramsaran-Fowdar, R. R. (2007). Developing a service quality questionnaire for the hotel industry in Mauritius. Journal of Vacation Marketing, 13(1), 19-17.

Rust, R. T., \& Oliver, R. L. (1994). Service quality: insights and managerial implications from the Frontier. In: R. T. Rust \& R. L. Oliver (Eds.), Service quality: New directions in theory and practice (pp. 1-19). Thousand Oaks, CA: Sage Publications.

Ryu, K., Han, H., \& Kim, T. H. (2008). The relationships among overall quick-casual restaurant image, perceived value, customer satisfaction, and behavioral intentions. International Journal of Hospitality Management, 27(3), 459-469.

Ryu, K., \& Han, H. (2010). Influence of the quality of food, service, and physical environmenton customer satisfaction in quickcasual restaurants: moderating role of perceived price. Journal of Hospitality \& Tourism Research, 34(3), 310-329.

Ryu, K., Lee, H. R., \& Kim, W. G. (2012). The influence of the quality of the physical environment, food, and service on restaurant image, customer perceived value, customer satisfaction, and behavioral intentions. International Journal of Contemporary Hospitality Management, 24(2), 200-223.

Sweeney, J. C., \& Soutar, G. N. (2001). Consumer perceived value: the development of a multiple item scale. Journal of Retailing, 77(2), 203-220.

Tran, V. D. (2020). Assessing the effects of service quality, experience value, relationship quality on behavioral intentions. Journal of Asian Finance, Economics and Business, 7(3), 167-175. https://doi.org/10.13106/jafeb.2020.vol7.no3.167

Tsiotsou, R. (2006). The role of perceived product quality and overall satisfaction on purchase intentions. International Journal of Consumer Studies, 30(2), 207-217

Won, J., \& Kim, B. Y. (2020). The effect of consumer motivations on purchase intention of online fashion-sharing platform. Journal of Asian Finance, Economics and Business, 7(6), 197-207. https://doi.org/10.13106/jafeb.2020.vol7.no6.197

Zeithaml, V. A., Berry, L. L., \& Parasuraman, A. (1996). The behavioral consequences of service quality. Journal of Marketing, 60(2), 31-46.

Zeithaml, V. A. (1998). Customer perception of price, quality and value: A means-end model and synthesis of evidence. Journal of Marketing, 52(3), 2-22.

Zeithaml, V. A. (2009). Service quality, profitability, and the economic worth of customers: What we know and what we need to learn. Journal of Academy of Marketing Science, 28(1), 67-85. 